\title{
The Status of Gumuz as a Language Isolate
}

\subsection{Introduction}

Gumuz (Ethiopia) along with the Koman (Coman) languages of Ethiopia/Sudan had been identified as Nilo-Saharan (N-S) since the time of Greenberg's original classification (Greenberg 1963, Bender 1997, Ehret 2001). More recently, however, doubt about Gumuz being a part of the N-S family has been raised (Mikkola 1999: 130, Dimmendaal 2008:843 ) with some suggesting that Gumuz may be an African language isolate (Bender 2005:916, Dimmendaal 2011:408).

I present new evidence in the form of regular sound correspondences which suggests that the Gumuz language cluster is at least related to the Koman languages, rendering it a possible member of the N-S family or at least a member of the Koman language family which may or may not be a member of N-S (Dimmendaal 2008, 2011). Other morphological similarities such as sex-based gender prefixes and number marking suggests that Gumuz may be related to the Nilotic languages (distantly or otherwise) and other languages within the greater N-S family. Relatively low cognate counts (based on fewer data) caused Bender (1979:40, 2000:56) to doubt that Gumuz had any special relationship with the Koman languages or with any proposed N-S language. However, with more data and inclusion of metathesized forms, the number of apparent shared cognate forms between Gumuz and Koman may exceed previous estimates.

\subsection{Gumuz and Koman}

Bender (1979:40) originally doubted Gumuz's membership in N-S due to the relatively low number of (apparaent) cognates shared between Gumuz and Koman and Gumuz and the rest of N-S. According to him, similarities between Gumuz and Koman merely exist due to contact (1997:63). However, these initially low cognate counts are likely the result of several factors: 1) little available data for Gumuz and Koman at the time Bender published 2) contact with Afroasiatic languages 3) unusual regular sound correspondences and 4) metathesized forms. I address the last two below.

\subsection{Regular Sound Correspondences between Gumuz and Koman}

Despite previous low cognate counts between Gumuz and Koman languages, I found one robust regular sound correspondence (Table 1) as well as a few weakly attested regular sound correspondences (Table 2).

Table 1

\begin{tabular}{|c|c|c|c|c|}
\hline & Gwama & S. Gumuz & N. Gumuz & Yaso Gumuz \\
\hline & $\mathrm{y}$ & $\mathrm{g} /[\mathrm{n}]$ & $x$ & $\varnothing$ \\
\hline 'clothes' & óx́ỳ̀ & aywa & aұwa & oa \\
\hline ‘sweep' & kéy & kant-íl & kaðat-1́l & kaat-1́l \\
\hline 'shell' & páyàk’ & páyk’a & páxák’a & páák’á \\
\hline 3S Pro & ùhày ùyáà & ána & áxó & á (ámé) \\
\hline 'spider' & t’útóóyó 'flea' & jántá tóywá & jantóxwa & jantoa \\
\hline 'fly (v)' & pày & poy & pó $\chi$ & po \\
\hline 'work, fix' & gíy & gán-áts & gáx-áts & - \\
\hline
\end{tabular}


The above robust sound correspondence is quite unusual and occurs between three Gumuz dialects (languages) and Gwama (Koman). This can be tentatively reconstructed as *k in proto-Gumuz with /y/ of Gwama corresponding with *k of proto-Gumuz (cf. Ahland 2012:29).

Following is a sample of other somewhat regular sound correspondences between Gumuz and Koman languages, not only Gwama. ${ }^{1}$

Table 2

\begin{tabular}{|c|c|c|c|c|c|}
\hline & Gwama & Komo & Opo & Uduk & Gumuz (all) \\
\hline & $\mathrm{p}$ & $\mathrm{p} / \mathrm{p}$ & $\mathrm{p}$ & $\mathrm{p}^{\mathrm{h}}$ & $\mathrm{f}, \varnothing / \ldots$ \\
\hline 'drink' & tóp & f́p & pii & $\mathrm{p}^{\mathrm{h}} \hat{1}$ & fá \\
\hline 'bathe' & óp & úp & upa & $u^{\mathrm{u}} \mathrm{p}^{\mathrm{h}}$ & af-, ef- \\
\hline 'rise' & - & - & piyey & $\mathrm{p}^{\text {héda }}$ & fád \\
\hline 'women' & - & ùp’ & o:po & $\bar{u} p^{h}$ & gááfa \\
\hline \multirow[t]{2}{*}{ 'head' } & úp & k'úp & k'up & k'úp ${ }^{\mathrm{h}}$ & lí-k’wá \\
\hline & $\mathrm{t}$ & k & $\mathrm{k} ?$ & c & c \\
\hline 'give' & tí & kà 'take' kì-ık 'give' & kie & cì & cá \\
\hline 'pay' & - & kishí 'to repay' & - & ciya & ciit (N. Gumuz) \\
\hline 'thorn' & - & káka & - & - & cíca \\
\hline \multirow[t]{2}{*}{ 'thigh' } & tíyàJá & - & - & - & c(')áfa \\
\hline & $\mathrm{y} ?$ & $\mathrm{y}$ & $\mathrm{y} ?$ & $\mathrm{y}$ & $\mathrm{w}$ \\
\hline 'vomit' & - & yà? & - & yá & wé? \\
\hline 'go (home)' & yìyé & yà & iyhá & ya & wá \\
\hline
\end{tabular}

\subsection{Metathesized forms between Gumuz and Koman}

In addition to regular sound correspondences between Gumuz and Koman, there also exist possible cognate forms which have been metathesized (Table 3 ).

Table 3

\begin{tabular}{|c|c|c|c|c|c|}
\hline Gloss & Gwama & Komo & Opo & Uduk & Gumuz (all) \\
\hline 'cook' & k’óz & k’ònzò & - & - & nz-ák’w [nzók’w] \\
\hline 'kill' & k’ú & k'ós & - & k’ós & Sá-k'w [Sók'w] \\
\hline 'steal' & - & kwál & - & kwāāl & lakw (S. Gumuz) \\
\hline 'cut' 'slice' & k’òb & - & - & k’áp & Gák'-1́l 'cut in two' \\
\hline 'hear' & - & sìg & - & - & gás \\
\hline 'slap' & Sáp 'hit' & Jàp' 'slap' & - & - & pás ‘slap’ \\
\hline 'arrive' & - & - & b'er & púd & dáb \\
\hline 'want, look for' & - & - & numa & yáp & pán \\
\hline
\end{tabular}

${ }^{1}$ Data for Gwama, Komo, Opo, and Uduk are taken from the following sources respectively: Kievet and Robertson 2011, Kutsch-Lojenga and Otero 2011, Lemi 2010, Beam and Cridland 1979. 
Most metatheses involve CVC(V) syllables while others appear to be metatheses of (historical?) morphemes, e.g. 'cook' which is comprised of the root $n z$ 'cook, fry' and the verbal classifier - Vk'W 'head' in Gumuz.

\subsection{Gender Prefixes in Gumuz and Nilotic}

The natural sex-based number marking system in Gumuz resembles masculine and feminine prefixes found in Nilotic. The sex-based masculine prefix in Gumuz is óo- for humans and oodá- [wədó-] for animals and is remarkably similar to that of Western Nilotic languages. Reh (1996) suggests the masculine gender prefix $o$ - in Anywa originated from an irregular modified form of wúídó 'son.' Similarly, Heine \& Vossen (1983) propose that the Western Nilotic masculine gender prefix $o$ - comes from a cliticized form of 'son' / wad/ (as found, for example, in Shilluk). Possible reflexes of the lexical source for the masculine gender prefix found in Gumuz and Western Nilotic can be found in masculine 3SG pronouns in Opo and various other lexemes of the Koman languages (possible reflexes shown in bold, Table 4).

Table 4

\begin{tabular}{|c|c|c|c|c|c|}
\hline & Gwama & Komo & Opo & Uduk & Gule (extinct) \\
\hline 3SG M & uhay & $\begin{array}{l}\text { hàr } \\
\text { ( hàp' 3SG F) }\end{array}$ & $\begin{array}{l}\text { ut-eni } \\
\text { (6e-eni 3SG F) }\end{array}$ & ádì & $\begin{array}{l}\text { ar } \\
(\mathrm{ab} 3 \mathrm{SG} F)\end{array}$ \\
\hline 3SG M POSS & $\mathrm{d} \varepsilon$ & $\begin{array}{l}\text {-eber } \\
\text { (-ebep F) }\end{array}$ & $\begin{array}{l}\text {-wotare } \\
\text { (-bare F) }\end{array}$ & -iti & $\begin{array}{l}-a r \\
(-a b F)\end{array}$ \\
\hline 'brother' & $\begin{array}{l}\text { wàl-kwám } \\
\text { child-father }\end{array}$ & kam & a-wuma & àkām & ádómnó \\
\hline husband & wútúp & gaz & kajum & àkās & - \\
\hline $\begin{array}{l}\text { 'child' } \\
\text { 'man' }\end{array}$ & wál 'child' & $\begin{array}{l}\text { at 'child' } \\
\text { at-gwàz 'boy' }\end{array}$ & $\begin{array}{l}\text { ukaj } \\
\text { 'adult male' }\end{array}$ & $\begin{array}{l}\text { wàtí } \\
\text { 'man' }\end{array}$ & àddád 'boy' \\
\hline
\end{tabular}

The feminine prefix in Gumuz is éé- for humans and eé(k'ó)- for animals. These prefixes are similar to feminine prefixes found in Eastern Nilotic languages like Maa. Compare sample Gumuz and Maa forms below.

$\begin{array}{ll}\text { Maa (Payne \& } & \text { Ole-Kotikash 2008) } \\ \text { En-kítén } & \text { ol-kítén } \\ \text { F-bovine } & \text { M- bovine } \\ \text { 'cow' } & \text { 'bull' }\end{array}$

$\begin{array}{ll}\text { Southern Gumuz } & \\ \text { eé(kó)-tanga } & \text { oodá-tanga } \\ \text { F- bovine } & \text { M- bovine } \\ \text { 'cow' } & \text { 'bull' }\end{array}$

Heine and Vossen (1983:253) reconstruct the lexical source of the feminine prefix for all of Nilotic as *nyaa- 'girl, daughter', which served as the head noun of a genitive construction meaning 'daughter of X'. Similarly, the feminine prefix éé- in Gumuz can be internally

\footnotetext{
${ }^{2}$ Such a form is curiously similar to the Arabic walad 'child.' This could be an early borrowing from Arabic into a (W.) Nilotic parent language which was then inherited in daughter languages.
} 
reconstructed as ea- 'mother', the (bound) head noun of an associative construction meaning 'mother of X' (Ahland 2012:98). The bound form, ea- could be a reflex of *nyaa 'girl, daughter' or of an earlier proto-form. This would seem likely especially if nà 'mother' of the Koman language Gwama (Kievet \& Robertson 2011) is indeed cognate with Gumuz ea-. Feminine gender in Koman languages, however, has a distinct lexical source.

\section{Number Marking in Nilo-Saharan}

Dimmendaal (2000) asserts that tripartite number marking (singulative, plural, and replacive) must have been a feature of proto-Nilo-Saharan and the lack of this feature in daughter languages must constitute a loss. In general, Gumuz and the Koman languages lack tripartite number marking but relics of these number marking strategies exist. Optional plural marking (má-) exists for nouns higher on the animacy hierarchy in Gumuz but this prefix is not cognate with the T/N/K markers found in Nilo-Saharan (cf. Bryan 1959, 1968, Dimmendaal 2000). On the other hand, the class morphemes $k$ 'wá- and $c a$ - are sometimes used to indicate number, with $k^{\prime} w a ́$ - individuating certain classes of nouns (singulative) and cá- serving as a marker of collective (plural). Certain nouns can use both $k^{\prime} w a ́$ - and cá- to indicate number (replacive) as shown in the table below. These may be cognate with $\mathrm{T} / \mathrm{K}$ pattern of number marking in which *K often marks plural but in some languages marks singular. ${ }^{3}$ In any case, there exists some relic of singulative/plural/replacive number marking in Gumuz.

Table 5

\begin{tabular}{|l|l|l|l|}
\hline Gloss & Noun root & Singular? & Plural/Collective \\
\hline 'rock' & gífá & k'wá-gífá & cá-gífá \\
\hline 'bone' & zákwá & k'wá-zákwá & cá-zákwá \\
\hline
\end{tabular}

Two Koman languages, Gwama and Opo, also have singulative markers in addition to plural markers. In Gwama, the singulative is $u$ - (Kievet \& Robertson 2011) and in Opo, the singulative is $u$-/o- (Lemi 2010). These may be cognate with the Southern Luo singulative -o (Dimmendaal 2000:245). Note also that the lexical source for the class morpheme $k$ 'wá- in Gumuz is $l i-k$ 'wá 'head' and that the cognate term for 'head' in Gwama is $u ́ p$ which may also be the lexical source for the $u$ - singulative.

\section{Conclusion}

Given new data available for Gumuz and Koman languages, regular sound correspondences and hence genetic relationship can be established between Gumuz and Koman languages. Metathesized forms found in Gumuz and Koman may also prove to be cognate. Other features of N-S languages such as gender marking in Nilotic may share common lexical sources with the sex-based gender marking in Gumuz. Lastly, traces of tripartite number marking which is a common pattern across N-S languages can be found in both Gumuz and Koman languages. Therefore it is not likely that Gumuz is an African isolate and, as once thought, it is most closely related to the Koman subfamily which may indeed prove to be part of the broader N-S superfamily.

\footnotetext{
${ }^{3}$ The same marker can be used to indicate either plural or singulative ("inverse" systems) in the Niger-Congo language Dagaare in which number marking is based on the subtle semantic principle of individuation (Grimm 2009). A parallel example can be found in Gumuz in which cá-, which is sometimes used to mark plural/collective, can be used as a means of individuating the mass/general noun aywa 'clothes' as in cá-aywa 'piece of cloth'.
} 
References

Ahland, Colleen. 2012. A grammar of Northern and Southern Gumuz. PhD dissertation, University of Oregon.

Beam, M. S. and E. A. Cridland. 1979. Uduk-English Dictionary. Volume 4 of Linguistics MonographSeries. Sudan Research Unit, University of Khartoum.

Bender, M. Lionel. 1979. Gumuz: a sketch of grammar and lexicon. Afrika und Übersee, 62. 3869.

Bender M. Lionel. 1997. The Nilo-Saharan languages: a comparative essay. Munich: Lincom Europa.

Bender, M. Lionel. 2000. Nilo-Saharan. African languages: an introduction, ed. by Bernd Heine and Derek Nurse, 43-73. Cambridge: Cambridge University Press.

Bender, M. Lionel. 2005. Gumuz. Encyclopaedia Aethiopica, Volume 2, ed. by Siegbert Uhlig. Wiesbaden: Harrassowitz Verlag.

Bryan, Margaret. 1959. The T/K languages: A new substratum. Africa 29.1-21.

Bryan, Margaret. 1968. The * $\mathrm{N} / * \mathrm{~K}$ languages of Africa. Journal of African Languages 7.169217.

Dimmendaal, Gerritt. J. 2000. Number marking and noun categorization in NiloSaharan languages. Anthrolopological Linguistics 42:214-261.

Dimmendaal, Gerritt. J. 2008. Language ecology and linguistic diversity on the African continent. Language and Linguistics Compass 2, 5:840-858.

Dimmendaal, Gerritt. J. 2011. Historical linguistics and the comparative study of African languages. Philadelphia: John Benjamins. Ehret, Christopher. 2001. A historicalcomparative reconstruction of Nilo-Saharan.Köln: Rüdiger Köppe Verlag.

Greenberg, Joseph. 1963. The languages of Africa. The Hague: Mouton.

Grimm, Scott. 2009. Individuation and inverse number marking in Dagaare. Count and mass across languages, ed. by Diane Massam, 75-98.Oxford: Oxford University Press.

Heine, Bernd \& Vossen, Rainer. 1983. On the origin of gender in Eastern Nilotic. Nilotic studies : proceedings of the International Symposium on Languages and History of the Nilotic Peoples, Cologne, January 4-6, 1982.

Lemi Kebebw. 2010. A grammatical description of Opo. Master's thesis, Addis Ababa University.

Kievit, Dirk and Erika Robertson. 2011. Notes on Gwama grammar with texts and word lists. Unpublished manuscript.

Payne, Doris L. and Ole-Kotikash, Leonard. 2008. Maa on-line dictionary. http://pages.uoregon.edu/maasai/Maa\%20Lexicon/lexicon/main.htm

Reh, Mechthild. 1996. Anywa language. Cologne: Köppe. 